Pesq. Vet. Bras. 38(4):629-634, abril 2018

\title{
Occurrence of subclinical metabolic disorders in dairy cows from western Santa Catarina state, Brazil ${ }^{1}$
}

\author{
Eliana L. Fiorentin ${ }^{2}$, Solange Zanovello ${ }^{2}$, Andrei Gato ${ }^{2}$, André L. Piovezan ${ }^{2}$, \\ Maurício V. Alves ${ }^{2}$, Ricardo X. Rocha ${ }^{2}$ and Félix Gonzalez ${ }^{3 *}$
}

\begin{abstract}
Fiorentin E.L., Zanovello S., Gato A., Piovezan A.L., Alves M.V., Rocha R.X. \& Gonzalez F. 2018. Occurrence of subclinical metabolic disorders in dairy cows from western Santa Catarina state, Brazil. Pesquisa Veterinária Brasileira 38(4):629-634. Faculdade de Veterinária, Universidade Federal do Rio Grande do Sul, Av. Bento Gonçalves 9090, Porto Alegre, RS 91540-000, Brazil. E-mail: felix.gonzalez@ufrgs.br

The management of dairy herds during the transition period has been studied in several studies due to the severe adjustments to which cows are submitted in the metabolism of carbohydrates, lipids and minerals at early lactation. This is a period when occurs most of the metabolic disorders in dairy cows, especially in their subclinical form. Hitherto a lack of information exists on the occurrence of subclinical metabolic disorders in Brazil. The aim of this study was to determine the occurrence of subclinical metabolic disorders, including ketosis, liver lipidosis, hypocalcemia, lactacidemia and hypomagnesemia, as well as phosphorous, copper and zinc deficiency in dairy cattle from the western region of Santa Catarina state, southern Brazil, during the first 30 days of lactation. Blood samples from 15 dairy herds managed in intensive production (free-stall) and semi-confined systems were collected. Milk yield, reproduction and health data of the herd were recorded in a questionnaire, based on the records of the farm and on the observations during samples collection. Blood samples were collected for the measurement of beta-hydroxybutyrate (BHB) and lactate using portable monitors at the farm and for obtaining serum to perform the following biochemical determinations: total calcium, phosphorus, magnesium, albumin, aspartate transaminase (AST) and creatine kinase (CK) by UV-visible spectrophotometry, and copper and zinc by atomic absorption spectrophotometry. In this study, the cutoff points considered were as follows: serum BHB concentrations $>1.2 \mathrm{mmol} / \mathrm{L}$ for subclinical ketosis, AST $>140 \mathrm{U} / \mathrm{L}$ and $\mathrm{CK}<94 \mathrm{U} / \mathrm{L}$ for subclinical liver lipidosis, serum lactate concentrations $>2.2 \mathrm{mmol} / \mathrm{L}$ for lactacidemia, serum total calcium concentrations $<7.5 \mathrm{mg} / \mathrm{dL}$ for subclinical hypocalcemia, serum magnesium concentration $<1.7 \mathrm{mg} / \mathrm{dL}$ for hypomagnesemia, serum phosphorus concentration $<2.5 \mathrm{mg} / \mathrm{dL}$ for phosphorus deficiency, serum copper concentrations $<32.8 \mu \mathrm{g} / \mathrm{dL}$ for copper deficiency, and serum zinc concentrations $<60 \mu \mathrm{g} / \mathrm{dL}$ for zinc deficiency. The results showed an occurrence of $9 \%$ for subclinical ketosis, $11 \%$ for subclinical liver lipidosis, $44.5 \%$ for lactacidemia, 11\% for subclinical hypocalcemia, 7.4\% for subclinical hypomagnesemia, $10.7 \%$ for copper deficiency and $8.7 \%$ for zinc deficiency. According to the survey results, the occurrence of subclinical ketosis, lipidosis and hypocalcemia in western Santa Catarina differ from data found in the literature
\end{abstract}

INDEX TERMS: Metabolic disorders, dairy cows, Brazil, cattle, epidemiology, ketosis, mineral deficiencies, clinics.

\footnotetext{
${ }^{1}$ Received on August 4, 2016.

Accepted for publication on April 28, 2017.

${ }^{2}$ Faculdade de Medicina Veterinária, Universidade do Oeste de Santa Catarina, Xanxerê, SC 89820-000, Brazil. E-mails: eliana.fiorentin@unoesc. edu.br, szanodello@hotmail.com,deki-06@hotmail.com, andrepiovezan@ outlook.com, mauricio.alves@unoesc.edu.br, ricardorocha.vet@gmail.com

${ }^{3}$ Faculdade de Veterinária, Universidade Federal do Rio Grande do Sul, Av. Bento Gonçalves 9090, Porto Alegre, RS 91540-000, Brazil. *Corresponding author: felix.gonzalez@ufrgs.br
}

RESUMO.- [Ocorrência de transtornos metabólicos subclínicos em vacas leiteiras da região Oeste do estado de Santa Catarina.] 0 manejo dos rebanhos leiteiros durante o período de transição tem sido objeto de estudo de diversas pesquisas devido às severas adaptações sofridas pelas vacas no metabolismo dos carboidratos, lipídeos e minerais no início da lactação. Trata-se de um período em que ocorre 
a maioria dos transtornos metabólicos em vacas leiteiras, especialmente na sua forma subclínica. Até hoje existe uma falta de informação sobre a ocorrência de transtornos metabólicos subclínicos no Brasil. 0 objetivo deste estudo foi determinar a ocorrência de transtornos metabólicos subclínicos, dentre eles cetose, lipidose hepática, lactacidemia, hipocalcemia e hipomagnesemia, bem como deficiências de fósforo, cobre e zinco, em bovinos leiteiros da região Oeste do estado de Santa Catarina, durante os primeiros 30 dias de lactação. Foram avaliadas amostras de 15 rebanhos leiteiros manejados em sistemas de produção intensiva (free-stall) e semi-confinamento. Dados de produção, reprodução e sanidade do rebanho e de cada animal utilizado no estudo foram registrados em um questionário, baseando-se nos registros da fazenda e nas observações durante as coletas. Amostras de sangue total foram coletadas para dosagem de beta-hidroxibutirato (BHB) e lactato através de monitores portáteis ao pé das vacas e para obter amostras de soro usadas nas seguintes determinações bioquímicas: cálcio total, fósforo, magnésio, albumina, AST e CK por espectrofotometria UV-visível, e cobre e zinco por espectrofotometria de absorção atômica. No presente trabalho, foram considerados os seguintes pontos de corte: concentrações séricas de BHB $>1,2 \mathrm{mmol} / \mathrm{L}$ para cetose subclínica, atividade sérica de AST $>132 \mathrm{U} / \mathrm{L}$ e de CK < 94U/L para lipidose hepática subclínica, concentrações séricas de lactato $>2,2 \mathrm{mmol} / \mathrm{L}$ para lactacidemia, concentrações séricas de cálcio total $<7,5 \mathrm{mg} / \mathrm{dL}$ para hipocalcemia subclínica, concentração sérica de magnésio $<1,7 \mathrm{mg} / \mathrm{dL}$ para hipomagnesemia subclínica, concentração sérica de fósforo $<2,5 \mathrm{mg} / \mathrm{dL}$ para deficiência de fósforo, concentrações séricas de cobre $<32,8 \mu \mathrm{g} / \mathrm{dL}$ para deficiência de cobre, e concentrações séricas de zinco $<60 \mu \mathrm{g} / \mathrm{dL}$ para deficiência de zinco. Foi encontrada ocorrência de $9 \%$ para cetose subclínica, 11\% para lipidose hepática subclínica, 44,5\% para lactacidemia, 11\% para hipocalcemia subclínica, $7,4 \%$ para hipomagnesemia, $10,7 \%$ para deficiência de cobre e 8,7\% para deficiência de zinco. De acordo com os resultados da pesquisa, as ocorrências de cetose, lipidose hepática e hipocalcemia subclínicas no Oeste Catarinense foram diferentes das encontradas em outros estudos.

TERMOS DE INDEXAÇÃO: Metabolismo, vacas leiteiras, Santa Catarina, bovinos, cetose, deficiência mineral, epidemiologia, clínica.

\section{INTRODUCTION}

The importance of dairy industry in Brazilian agriculture is expressive and its development has led to intensification of the dairy production systems in order to make more profit with minimal cost. Therefore, genetic selection has been directed toward the production of high-yielding cows, which are metabolically required to meet production needs, increasing the risk of developing metabolic disorders (Buckley et al. 2000).

In 2014, the southern region of Brazil occupied first place in ranking of Brazilian regions in cow milk production, with 12.2 million tons (IBGE 2014). The increase in production was $3.6 \%$ between 2013 and 2014 at the regional level, while the national production increased by $2.7 \%$ in this period. In addition, the southern region had the highest national productivity $(2,789 \mathrm{~L} / \mathrm{cow} /$ year $)$ representing an increase of $4.3 \%$ in 2014 , compared to the previous year. The state of Rio Grande do Sul had the highest national productivity $(3,034 \mathrm{~L} / \mathrm{cow} /$ year $)$, followed by the states of Santa Catarina $(2,694 \mathrm{~L} / \mathrm{cow} /$ year $)$ and Paraná (2,629 L/cow/year) (IBGE 2014).

The most significant metabolic changes in dairy cows comprise the transition period, beginning at the last three weeks of pregnancy and extending into the third week of lactation (Tedesco et al. 2004). The nutritional management of dairy cows during the transition period has been deeply studied due to the severe adjustments that cows must face in the metabolic challenge of high milk yield (Overton \& Waldron 2004). When the nutrient imbalance is moderate, metabolism compensates by using their body reserves. However, if the imbalance is severe, the animal exhausts its reserves and may develop a metabolic disorder (Wittwer 2000).

In the transition period, subclinical metabolic disorders are more common than clinical disorders but also are more difficult to diagnose (Mulligan \& Doherty 2008). In dairy cows, the most common metabolic disorders studied along the past decades are ketosis, hepatic lipidosis, metabolic or ruminal acidosis, hypocalcemia, hypomagnesemia, and deficiencies of phosphorus, copper and zinc (Chapinal et al. 2011). In a review paper, Ingvartsen et al. (2003) reported that the incidence of clinical hypocalcemia ranged between 0.2 and $8.9 \%$ and clinical ketosis ranged between 0.2 and $10 \%$ in herds from Finland and North America, while Kelton et al. (1998) reported incidence between 0.03 and $22.3 \%$ for hypocalcemia and between 1.3 and $18.3 \%$ for ketosis in herds from the US, UK and Finland. There is a lack of information regarding the occurrence of subclinical metabolic disorders in dairy cattle in southern Brazil. Therefore, the objective of this study was to determine the occurrence of some subclinical metabolic disorders in dairy cattle during the early lactation period in the western zone of Santa Catarina state, southern Brazil.

\section{MATERIALS AND METHODS}

Ethics statement. All procedures with the cows of this study were approved by the Ethics Committee on Animal Use of the Federal University of Rio Grande do Sul and authorized by the herd owners.

Animals. A total of 299 Holstein cows were evaluated during early lactation (from calving to 30 days of lactation) in 15 herds located in the following seven municipalities of the western region of Santa

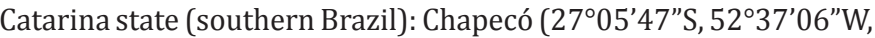

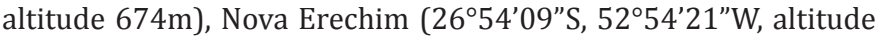
$462 \mathrm{~m})$, Ouro Verde $\left(26^{\circ} 41^{\prime} 40^{\prime \prime} \mathrm{S}, 5^{\circ}{ }^{\circ} 18^{\prime} 43^{\prime \prime} \mathrm{W}\right.$, altitude $\left.758 \mathrm{~m}\right)$, Quilombo

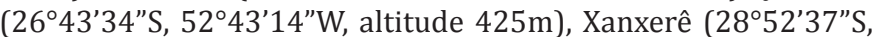
$52^{\circ} 24^{\prime} 15^{\prime \prime} \mathrm{W}$, altitude $\left.800 \mathrm{~m}\right)$, Xavantina $\left(27^{\circ} 04^{\prime} 07^{\prime \prime} \mathrm{S}, 52^{\circ} 20^{\prime} 31^{\prime \prime} \mathrm{W}\right.$, altitude $545 \mathrm{~m}$ ) and Xaxim ( $26^{\circ} 57^{\prime} 42^{\prime \prime}$ S, $52^{\circ} 32^{\prime} 05^{\prime \prime} \mathrm{W}$, altitude $770 \mathrm{~m}$ ). According to the Koppen classification, those locations are in a transition area between the types of climate $\mathrm{Cfb}$ (mesothermal, humid without dry season, cool summers, with occurrence of severe and frequent frosts in winter) and Cfa (mesothermal, humid without dry season, hot summers, with rare frosts in winter) (Puchalski 2004).

From the 15 herds studied, three were managed by confined (free-stall) system and 12 by semi-confined system. Of the 299 cows that made up the study, $182(60.9 \%)$ were raised in free-stall system, and 117 (39.1\%) were in semi-confined system. All cows in free-stall system and 105 cows (89.7\%) in semi-confined system were supplemented with anionic salt (ammonium chloride, calcium chloride, ammonium sulfate, calcium sulfate and magnesium sulfate) during the prepartum period for preventing hypocalcemia. Only one herd of 12 lactating cows did not use anionic salt. Data concerning days in milk, number of lactation, milk production and body condition score were obtained from all animals (Table 1). 
The diet of the animals was composed of corn silage, pastures (ryegrass, oats and barley) plus hay. The concentrate contained corn, soybean meal and mineral supplement. The body score was assessed by subjective method, through observation on the scale of 1 to 5 (Edmonson et al. 1989), where score 1 is very lean and score 5 very fat. Production data (individual cow and herd mean), date of calving, days in lactation, body condition score, and number of lactations of the animals of all herds were recorded in a questionnaire filled with the help of veterinarian responsible for the herd. Also, in the questionnaire, clinical cases of postpartum diseases observed by the veterinarians were recorded (ketosis, ruminal acidosis, hypocalcemia, placental retention, abomasum displacement, metritis and mastitis).

Sample collection and analysis. Blood samples were collected in cows up to 30 days of lactation through coccygeal venipuncture after local asepsis, using vacutainer tubes without anticoagulant and with heparin (Vacuette, Brazil). The distribution of sampled animals according to the days in lactation (DEL) was as follows: 63 cows from 0 to 7 DEL, 78 from 8 to 15 DEL, 97 from 16 to 23 DEL and 61 from 24 to $30 \mathrm{DEL}$. All samples were collected during feeding period after milking. Immediately after collection, an aliquot of anti-coagulated blood was used for measurement of beta-hydroxybutyrate (BHB) through portable monitor and specific strip (Ketovet, TaiDoc, Korea) according to the manufacturer's instructions. Another aliquot of this sample was used for measurement of lactate using a portable monitor and specific strip (Accutrend Plus, Roche, USA) according to manufacturer's instructions. During transportation, blood samples were put under refrigeration and forwarded to the laboratory where they were centrifuged (2,500rpm for 10 minutes) to obtain serum. Serum samples were placed in eppendorf tubes and stored at $-20^{\circ} \mathrm{C}$ until biochemical determinations.

Biochemical measurements of total calcium, phosphorus, magnesium, aspartate transaminase (AST) and creatine kinase (CK) were carried out using semi-automatic equipment (Bio2000, Bioplus, Brazil) by UV-visible spectrophotometry using commercial kits (Labtest, Brazil). Copper and zinc were determined by atomic absorption spectrophotometry in automatic device (Aanaliser 200, PerkinElmer, USA). Cases of subclinical metabolic disorders and mineral deficiencies were considered, using the following cutoffs values: serum BHB concentrations $>1.2 \mathrm{mmol} / \mathrm{L}$ for subclinical ketosis (McArt et al. 2012), AST >140U/L and CK <94U/L for subclinical liver lipidosis (Kaneko et al. 2008), serum total calcium concentrations $<7.5 \mathrm{mg} / \mathrm{dL}$ for subclinical hypocalcemia (Goff et al. 1996), serum lactate concentrations $>2.2 \mathrm{mmol} / \mathrm{L}$ for lactacidemia (Kaneko et al. 2008), serum phosphorus concentration $<2.5 \mathrm{mg} / \mathrm{dL}$ for phosphorus deficiency (McDowell 2003), serum magnesium concentration $<1.7 \mathrm{mg} / \mathrm{dL}$ for magnesium deficiency (Kaneko et al. 2008 ), serum copper concentrations $<32.8 \mu \mathrm{g} / \mathrm{dL}$ for copper deficiency (Puls 1988), and serum zinc concentrations $<60 \mu \mathrm{g} / \mathrm{dL}$ for zinc deficiency (Puls 1988).

Statistics. Data were entered in Excel sheet (Microsoft, USA), for calculation of subclinical occurrence rates of ketosis, hepatic lipidosis, lactacidemia, hypocalcemia, hypomagnesemia and copper and zinc deficiency using the following formula: Occurrence rate of disorder $=$ [number of new cases/number of cows under risk] $\mathrm{x} 100$. Cows under risk were considered those in the first 30 days of lactation.

Quantitative variables were described by mean, standard deviation, minimum and maximum values, and compared between groups by Student $t$ test for independent samples. Categorical variables were determined applying a test of proportions (Chi square). In both tests a range of $95 \%$ confidence was considered $(\mathrm{P}<0.05)$.

\section{RESULTS}

The dairy herds analyzed in the western region of Santa Catarina state, had a total occurrence of $9 \%$ for subclinical ketosis, $11.4 \%$ for subclinical hepatic lipidosis, $44.5 \%$ for lactacidemia, $11 \%$ for subclinical hypocalcemia and $7.4 \%$ for subclinical hypomagnesemia. The occurrence of mineral deficiencies was $10.7 \%$ for copper and $8.7 \%$ for zinc. There were no cases of phosphorus deficiency. The production system (confined and semi-confined) did not show difference in the occurrence of the various disorders (Table 2). When analyzing the occurrence of subclinical metabolic disorders in relation to milk production (Table 3), a higher occurrence of subclinical hepatic lipidosis were seen in cows with milk yield below $15 \mathrm{~L} /$ cow/day $(\mathrm{P}<0.05)$.

Table 1. Production traits (mean \pm standard deviation) of the cows studied

\begin{tabular}{lcc}
\hline \multirow{2}{*}{\multicolumn{1}{c}{ Parameters }} & \multicolumn{2}{c}{ Production system } \\
\cline { 2 - 3 } & $\begin{array}{c}\text { Free-stall } \\
\text { confinement }\end{array}$ & $\begin{array}{c}\text { Semi- } \\
\text { confinement }\end{array}$ \\
\hline Number of cows & 182 & 117 \\
Days in lactation & $16.7 \pm 8.5$ & $14.6 \pm 8.6$ \\
Number of lactations & $2.2 \pm 1.4$ & $2.9 \pm 1.7$ \\
Milk yield (L/cow/day) & $24.5 \pm 9.7$ & $23.0 \pm 7.3$ \\
Body condition score (1-5) & $2.7 \pm 0.5$ & $3.0 \pm 0.5$
\end{tabular}

Table 2. Occurrence (\%) of subclinical metabolic disorders in cows from western Santa Catarina state, Brazil, according to the production system

\begin{tabular}{lcc}
\hline \multicolumn{1}{c}{ Disorder } & $\begin{array}{c}\text { Free-stall } \\
\text { confinement }\end{array}$ & Semi-confinement \\
\hline $\mathrm{N}$ & 182 & 117 \\
Ketosis & 4.0 & 5.0 \\
Liver lipidosis & 14.8 & 6.0 \\
Lactacidemia & 26.8 & 17.7 \\
Hypocalcemia & 6.2 & 5.0 \\
Hypomagnesemia & 5.3 & 2.0 \\
Phosphorus deficiency & 0 & 0 \\
Copper deficiency & 6.7 & 4.0 \\
Zinc deficiency & 4.7 & 4.0
\end{tabular}

Table 3. Occurrence (\%) of subclinical metabolic disorders in cows from western Santa Catarina state, Brazil, according to the milk yield level

\begin{tabular}{lccc}
\hline \multirow{2}{*}{ Disorder } & \multicolumn{3}{c}{ Milk yield (L/cow/day) } \\
\cline { 2 - 4 } & $<15$ & $15-30$ & $>30$ \\
\hline $\mathrm{N}$ & 59 & 173 & 67 \\
Ketosis & 8.5 & 6.9 & 14.9 \\
Liver lipidosis & $23.7^{\mathrm{a}}$ & $7.5^{\mathrm{b}}$ & $10.4^{\mathrm{b}}$ \\
Lactacidemia & 47.5 & 45.7 & 38.8 \\
Hypocalcemia & 13.6 & 11.0 & 11.9 \\
Hypomagnesemia & 8.5 & 6.9 & 7.5 \\
Phosphorus deficiency & 0 & 0 & 0 \\
Copper deficiency & 11.9 & 9.2 & 13.4 \\
Zinc deficiency & 16.9 & 5.8 & 8.9
\end{tabular}

a,b Different letters in the same line indicate statistical difference among groups $(\mathrm{p}<0.05)$. 
There was no significant difference $(P>0.05)$ in the occurrence of subclinical hypocalcemia comparing the cows that consumed ( $\mathrm{N}=287$, occurrence $17.7 \%)$ to the cows that did not consume $(\mathrm{N}=12$, occurrence $16.7 \%)$ anionic salt during prepartum period. The multiparous $(\mathrm{N}=197)$ and the primiparous $(\mathrm{N}=102)$ cows did not show any difference in the occurrence rates of subclinical metabolic disorders. The cows with a body condition score between 3.25 and 3.75 had a higher occurrence $(\mathrm{P}<0.05)$ of subclinical ketosis (20\%) than cows with less score (7.3\%).

\section{DISCUSSION}

The metabolic profile test has been used as a practical tool in dairy herds to improve feeding management, detect subclinical metabolic disorders and prevent production diseases (Kida 2002). We used the measurement of specific biochemical analytes in blood to detect the most important subclinical metabolic disorders in dairy herds from southern Brazil.

The occurrence of subclinical ketosis in western Santa Catarina was lesser (9\%) than the values reported by other studies in the southern region of Brazil, as Gonçalves (2015) who mentioned an prevalence of $35 \%$ of this disorder or Garcia et al. (2011) who found 24\% in cows from the state of Rio Grande do Sul. Cucunubo et al. (2013) found 14.8\% of subclinical ketosis in dairy cows from southern Chile and Garro et al. (2014) in Argentina found similar values of subclinical ketosis to our study (10.3\%). Those differences in the incidence rates of subclinical ketosis may be ascribed to the cutoff point of BHB considered for declaring a cow with the disorder, and also to the day of lactation when the cow was sampled. The current consensus is to consider a cutoff point of BHB at least of $1.2 \mathrm{mmol} / \mathrm{L}$ for subclinical ketosis (McArt et al. 2012).

Herds with high prevalence of subclinical ketosis in early lactation tend to have an increased incidence of displaced abomasum and clinical ketosis (Oetzel 2004). Duffield et al. (2009) stated that hyperketonemia is also a risk factor for metritis. Though it was not an objective of our work to establish risk factors due to the low number of animals, proportionally more cows with subclinical ketosis suffered metritis (11\%) compared to those that did not have subclinical ketosis $(8 \%)$. Asl et al. (2011) state that the prevalence of subclinical ketosis is greatest in high-yielding dairy cows and in cows with two or more lactations. In our study, although no significant differences were observed in subclinical ketosis occurrence among cows with different production levels (Table 3) the occurrence of this disorder was almost double in cows yielding more than $30 \mathrm{~L} /$ day that in cows producing $15-30 \mathrm{~L} /$ day (14.9 vs. $6.9 \%$ ). Primiparous and multiparous cows, however, had a similar occurrence of subclinical ketosis (7.8 and 9.6\% respectively). In our study, it was likely that the body condition score is a parameter more related to occurrence of subclinical ketosis once the higher the score at early lactation the more occurrence of the disorder.

Bobe et al. (2004) reviewed data of European dairy herds between 1980 and 2001, and found that the incidence of moderate hepatic lipidosis is 20 to $65 \%$, while the incidence of severe lipidosis is 5 to $24 \%$. In our study, the occurrence of subclinical hepatic lipidosis based on AST levels above $140 \mathrm{U} / \mathrm{L}$ concomitant with CK levels below 94U/L, was $15.7 \%$. Both enzymes are present in muscle tissue but the increase in AST without the increment in CK indicates liver lesion, most probably from esteatosis in early lactation cows (Liu et al. 2012). Liver lipidosis may be related to disorders after calving, as hypocalcemia, ketosis, displaced abomasum or any situation that curse with anorexia, as retained placenta or dystocia (Allen \& Piantoni 2013). In our study $9 \%$ of the cows with subclinical liver lipidosis suffered displaced abomasum, comparing to only $1 \%$ of the healthy cows.

Lactacidemia may occur as a consequence of ruminal acidosis, a very common disorder derived from the use of high grain diets, which is broadly used in high-yielding dairy cows (Tajik \& Nazifi 2011). Other causes of lactacidemia include hypovolemic shock, septic shock, and any other cause of decreased tissue perfusion leading to ischemia and necrosis (Russell \& Roussel 2007), which can be disregarded in the present work. The only accepted tool of diagnosis of ruminal acidosis is the measurement of ruminal $\mathrm{pH}$, not always a method easy to perform at the field (Enemark et al. 2002). As in this study we did not measured ruminal $\mathrm{pH}$, we intended to estimate a condition of lactacidemia, based on the measurement of blood lactate. Rodrigues (2009) correlated ruminal $\mathrm{pH}$ and ruminal concentrations of lactate in cattle, observing a high negative correlation between these two variables $\left(\mathrm{R}^{2}=0.9127\right)$. The same author correlated ruminal lactate and blood lactate, noting a significant positive correlation between the two variables $\left(\mathrm{R}^{2}=0.718\right)$. Therefore, it has been suggested that the measurement of blood lactate has good correlation with ruminal lactate. The occurrence of lactacidemia (above $2,2 \mathrm{mmol} / \mathrm{L}$ ) in our study was $44.5 \%$. Field studies have shown that in the US, more than $19 \%$ of cows in early lactation and $26 \%$ of cows in mid-lactation have subclinical rumen acidosis (Garret et al. 1997) while Kleen et al. (2013) stated that, in German herds, the prevalence of subclinical acidosis is up to $50 \%$ regardless of the milk production level. In the present study, we do not have reliable data for suggesting the occurrence of ruminal acidosis. We suggest that an approach for diagnosing metabolic acidosis can comprise the measurement of blood and ruminal lactate.

According to a survey done by Reinhardt et al. (2011) subclinical hypocalcemia in US dairy herds has an incidence of $25-54 \%$, in the first $48 \mathrm{~h}$ after calving, considering as the cutoff point serum calcium concentration of $8.0 \mathrm{mg} / \mathrm{dL}$. In our study the occurrence of hypocalcemia was 11\%. Goff et al. (1996) reinforce that the occurrence of subclinical hypocalcemia has been reported up to 10 days after calving. The early period of lactation studied and the cutoff point considered by those authors may explain the lower occurrence in our study, since we included cows up to 30 days in milk and use a cutoff point of $7.5 \mathrm{mg} / \mathrm{dL}$. Hypocalcemia may affect approximately $50 \%$ of the adult dairy cows not receiving anionic salts in prepartum period and $30 \%$ of the cows that consume anionic salts (Melendez et al. 2002). In our study, however, no significant difference was observed in the occurrence of subclinical hypocalcemia comparing cows that consumed with those that did not consume anionic salts before calving. Bouda et al. (2000) cited that subclinical hypocalcemia leads to decreased muscle tone, which can cause displacement of abomasum. Nevertheless, in our study only 1 cow out of 51 cows (less than $2 \%$ ) that suffer subclinical hypocalcemia had displaced abomasum. Also, the milk production levels did not influence the occurrence of subclinical hypocalcemia, 
although Correa et al. (2010) consider the high milk yield as a predisposing factor for clinical hypocalcemia, so that low yielding cows rarely have hypocalcaemia.

According to McDowell (2003), the incidence of clinical hypomagnesemia in dairy cattle is low $(<2 \%)$ but few studies indicate the incidence of subclinical condition. We found an occurrence of hypomagnesemia of $7.4 \%$. Magnesium is involved in various enzymatic reactions of the intermediary metabolism and its deficiency can affect various physiological activities, mainly by diminishing the reproductive performance (Dugmore et al. 1987). McDowell (2003) also cites immunity and muscle contraction as physiological events affected by magnesium deficiency, which may be a risk factor in the occurrence of metritis. Nevertheless, this was not the case in our study, where 25 cases of clinical metritis occurred in cows with normomagnesemia and no one case in cows with hypomagnesemia. Deficiency in magnesium absorption may be caused by high levels of phosphorus, potassium and nitrogen in the diet (McDowell 2003). In our study, the mean phosphorus concentration in serum $(10 \mathrm{mg} / \mathrm{dL})$ was above the reference value for cows $(5.6-6.5 \mathrm{mg} / \mathrm{dL})$, which may reveal excessive intake of this mineral and one possible cause for the occurrence of subclinical hypomagnesemia. In other regions of Brazil, like the state of Minas Gerais, serum phosphorus range of 4.45 to $5.63 \mathrm{mg} / \mathrm{dL}$ was found in lactating cows (Dayrell \& Resz 1984).

The occurrence of subclinical copper deficiency in our study was $10.7 \%$. In Santa Catarina, Tokarnia et al. (2000) reported copper deficiency in ruminants. Risk factors for copper deficiency include older animals, high mineral demand during pregnancy or lactation, poor availability of copper in the mineral supplement, soil characteristics and concentrations of other minerals such as molybdenum and sulfur (Overton \& Yasui 2014). It is suggest more studies regarding this deficiency and its relation with the occurrence of abomasal displacement. In our study the only one case of displaced abomasum belonged to a cow with copper deficiency.

The low occurrence of zinc deficiency in our study (8.7\%) contrast with the finding of Moraes (1998) in the states of Ceara and Piaui (northeastern Brazil) when more than $50 \%$ of the animals showed low levels of this mineral, suggesting the occurrence of subclinical zinc deficiency, although without any evidence of clinical disorder. In Brazil, most research on zinc deficiency has been conducted with beef cattle. Sousa et al. (1982) in the state of Mato Grosso found low levels of hepatic zinc in cattle from six herds while Lisboa et al. (1996) did not find evidence of zinc deficiency analyzing the hepatic content of zinc in bovines in the state of São Paulo.

\section{CONCLUSIONS}

In the western region of Santa Catarina state, the occurrence of subclinical ketosis is lesser than in other Brazilian regions and more similar to that of Argentinean herds.

Subclinical hepatic lipidosis has lower occurrence than those reported by authors from Europe and it is suggested that this disorder may be a risk factor for displaced abomasum.

The occurrence of subclinical hypocalcemia is lower than those found in the literature, fact attributable to the lactation period and the cutoff values used in our work.

It is likely that in the studied herds exist excess intake of phosphorus in the diet.
The occurrence of zinc and copper deficiencies, although relatively low, are worth of considering by veterinarians from the studied region.

Acknowledgements.- The authors are grateful to the University of West Santa Catarina, for the availability of laboratories and human resources for the analyses.

\section{REFERENCES}

Allen M.S. \& Piantoni P. 2013. Metabolic control of feed intake: implications for metabolic disease of fresh cows. Vet. Clin. N. Am., Food Anim. Pract. 29(2):279-297. http://dx.doi.org/10.1016/j.cvfa.2013.04.001. PMid:23809892.

Asl A.N., Nazifi S., Ghasrodashti A.R. \& Olyaee A. 2011. Prevalence of subclinical ketosis in dairy cattle in the southwestern Iran and detection of cutoff point for NEFA and glucose concentrations for diagnosis of subclinical ketosis. Prev. Vet. Med. 100(1):38-43. http://dx.doi.org/10.1016/j. prevetmed.2011.02.013. PMid:21439662.

Bobe G., Young J.W. \& Beitz D.C. 2004. Pathology, etiology, prevention, and treatment of fatty liver in dairy cows. J. Dairy Sci. 87(10):3105-3124. http://dx.doi.org/10.3168/jds.S0022-0302(04)73446-3.PMid:15377589.

Bouda J., Quiroz-Rocha G.F. \& Gonzalez F.H.D. 2000. Desequilíbrios de cálcio, fósforo e magnésio, p.47-52. In: González F.H.D., Borges J.B. \& Cecim M. (Eds), Uso de Provas de Campo e Laboratório Clínico em Doenças Metabólicas e Ruminais dos Bovinos. Universidade Federal do Rio Grande do Sul, Porto Alegre.

Buckley F., Dillon P., Rath M. \& Veerkamp R.F. 2000. The relationship between genetic merit for yield and live weight, condition score and energy balance of spring calving Holstein-Friesian dairy cows on grass based systems of milk production. J. Dairy Sci. 83(8):1878-1886. http://dx.doi.org/10.3168/ jds.S0022-0302(00)75060-0. PMid:10984166.

Chapinal N., Carson M., Duffield T.F., Capel M., Godden S., Overton M., Santos J.E.P. \& LeBlanc S.J. 2011. The association of serum metabolites with clinical disease during the transition period. J. Dairy Sci. 94(10):4897-4903. http:// dx.doi.org/10.3168/jds.2010-4075. PMid:21943741.

Correa M.N., Gonzalez F.H.D. \& Silva S.C. 2010. Transtornos Metabólicos nos Animais Domésticos. Editora Universitária PREC/UFPEL, Pelotas.

Cucunubo L.G., Strieder-Barboza C., Wittwer F. \& Noro M. 2013. Diagnóstico de cetosis subclínica y balance energético negativo en vacas lecheras mediante el uso de muestras de sangre, orina y leche. Revta Cient. FCVLuz 23(2):111-119.

Dayrell M.S. \& Resz F. 1984. Teor de fósforo inorgânico no soro sanguíneo de vacas em lactação da região da Zona da Mata. Pesq. Agropec. Bras. 19:1307-1312.

Duffield T.F., Lissemore K.D., McBride B.W. \& Leslie K.E. 2009. Impact of hyperketonemia in early lactation dairy cows on health and production. J. Dairy Sci. 92(2):571-580. http://dx.doi.org/10.3168/jds.2008-1507. PMid:19164667.

Dugmore T.J., Lesch S.F. \& Walsh K.P. 1987. The effect of magnesium oxide supplementation on the fertility of dairy cows grazing fertilized pastures. S. Afr. J. Anim. Sci. 17:183-185.

Edmonson A.J., Lean I.J., Weaver L.D., Farver T. \& Webster G. 1989. A body condition scoring chart for Holstein dairy cows. J. Dairy Sci. 72(1):68-78. http://dx.doi.org/10.3168/jds.S0022-0302(89)79081-0.

Enemark J.M.D., Jorgensen R.J. \& Enemark P.S. 2002. Rumen acidosis with special emphasis on diagnostic aspect of subclinical rumen acidosis: a review. Veterinarija ir Zootechnika 42:16-29.

Garcia A.M., Cardoso F.C., Campos R., Thedy D.X. \& Gonzalez F.H.D. 2011. Metabolic evaluation of dairy cows submitted to three different strategies to decrease the effects of negative energy balance in early postpartum. 
Pesq. Vet. Bras. 31(Suppl. 1):11-17. http://dx.doi.org/10.1590/S0100736X2011001300003.

Garret E.F., Norlund K.V., Goodger W. \& Oetzel G.R. 1997. A cross-sectional field study investigating the effect of periparturient dietary management on ruminal pH in early lactation dairy cows. J. Dairy Sci. 80:169.

Garro C.J., Mian L. \& Cobos-Roldán M. 2014. Subclinical ketosis in dairy cows: prevalence and risk factors in grazing production system. J. Anim. Physiol. Anim. Nutr. 98(5):838-844. http://dx.doi.org/10.1111/jpn.12141. PMid:24236545.

Goff J.P., Horst R.L., Jardon P.W., Borelli C. \& Wedam J. 1996. Fields trials of an oral calcium propionate paste as an aid to prevent milk fever in periparturient dairy cows. J. Dairy Sci. 79(3):378-383. http://dx.doi. org/10.3168/jds.S0022-0302(96)76375-0. PMid:8708097.

Gonçalves R.S. 2015. Eficácia da administração de drench em vacas recémparidas na prevenção de cetose, hipocalcemia subclínica, e seu efeito sobre a qualidade do leite. Dissertação de Mestrado, Programa de Pósgraduação em Ciências Veterinárias, Universidade Federal do Rio Grande do Sul, Porto Alegre. 37p.

IBGE 2014. Instituto Brasileiro de Geografia e Estatística. Available in <http:// www.sidra.ibge.gov.br/bda/tabela/protabl.asp?c $=94 \& \mathrm{z}=\mathrm{p} \& 0=28 \& \mathrm{i}=\mathrm{P}>$ Accessed on Feb. 15, 2015.

Ingvartsen K.L., Dewhurst R.J. \& Friggens N.C. 2003. On the relationship between lactational performance and health: is it yield or metabolic imbalance that cause production diseases in dairy cattle? A position paper. Livest. Prod. Sci. 83(2/3):277-308. http://dx.doi.org/10.1016/ S0301-6226(03)00110-6.

Kaneko J.J., Harvey J.W. \& Bruss M.L. 2008. Clinical Biochemistry of Domestic Animals. 6th ed. Academic Press, San Diego.

Kelton D.F., Lissemore K.D. \& Martin R.E. 1998. Recommendations for recording and calculating the incidence of selected clinical diseases in dairy cattle. J. Dairy Sci. 81(9):2502-2509. http://dx.doi.org/10.3168/ jds.S0022-0302(98)70142-0. PMid:9785242.

Kida K. 2002. The metabolic profile test: its practicability in assessing feeding management and periparturient diseases in high yielding commercial dairy herds. J. Vet. Med. Sci. 64(7):557-563. http://dx.doi.org/10.1292/ jvms.64.557. PMid:12185307.

Kleen J.L., Upgang L. \& Rehage J. 2013. Prevalence and consequences of subacute ruminal acidosis in German dairy herds. Acta Vet. Scand. 55(1):4853. http://dx.doi.org/10.1186/1751-0147-55-48. PMid:23805878.

Lisboa J.A., Kuchembuck M.R. \& Kohayagawa A. 1996. Resultados de patologia clínica e dosagens de elementos minerais em bovinos acometidos pelo botulismo epizoótico no Estado de São Paulo. Pesq. Vet. Bras. 16:91-97.

Liu P., He P.X., Yang X.L., Hou X.L., Zhao H.Y., Han Y.H., Nie P., Deng H.F. \& Cheng L. 2012. Activities of aspartate aminotransferase, alanine aminotransferase, gamma-glutamyltransferase, alkaline phosphatase in plasma of postpartum Hosltein cows. J. Anim. Vet. Adv. 11(8):1270-1274. http://dx.doi.org/10.3923/ javaa.2012.1270.1274

McArt J.A., Nydam D.V. \& Oetzel G.R. 2012. Epidemiology of subclinical ketosis in early lactation dairy cattle. J. Dairy Sci. 95(9):5056-5066. http://dx.doi. org/10.3168/jds.2012-5443. PMid:22916909.

McDowell L.R. 2003. Minerals in Animal and Human Nutrition. Elsevier Science, Amsterdam. 644p.

Melendez P., Donovan A., Risco C.A., Hall M.B., Littell R. \& Goff J. 2002. Metabolic responses of transition Holstein cows fed anionic salts and supplemented at calving with calcium and energy. J. Dairy Sci. 85(5):1085-1092. http:// dx.doi.org/10.3168/jds.S0022-0302(02)74169-6. PMid:12086042.

Moraes S.S. 1998. Avaliação das concentrações de zinco, manganês e ferro no fígado de bovinos e ovinos de várias regiões do Brasil. Pesq. Vet. Bras. 18(3/4):107-110. http://dx.doi.org/10.1590/S0100-736X1998000300003.

Mulligan F.J. \& Doherty M.L. 2008. Production diseases of the transition cow. Vet. J. 176(1):3-9. http://dx.doi.org/10.1016/j.tvjl.2007.12.018. PMid:18342556.

Oetzel G.R. 2004. Monitoring and testing dairy herds for metabolic disease. Vet. Clin. N. Am., Food Anim. Pract. 20(3):651-674. http://dx.doi.org/10.1016/j. cvfa.2004.06.006. PMid:15471629.

Overton T.R. \& Waldron M.R. 2004. Nutritional management of transition dairy cows: strategies to optimize metabolic health. J. Dairy Sci.87(Suppl.):E105-E109. http://dx.doi.org/10.3168/jds.S0022-0302(04)70066-1.

Overton T.R. \& Yasui T. 2014. Practical applications of trace minerals for dairy cattle. J. Anim. Sci. 92(2):416-426. http://dx.doi.org/10.2527/jas.20137145. PMid:24305870.

Puchalski A. 2004. Variações edafo-climáticas e ocorrência natural da Araucaria angustifloria no estado de Santa Catarina. Dissertação de Mestrado, Centro de Ciências Agrárias, Universidade Federal de Santa Catarina, Florianópolis. 75p.

Puls R. 1988. Mineral Levels in Animal Health: Diagnostic Data. Sherpa International, Madison.

Reinhardt T.A., Lippolis J.D., McCluskey B.J., Goff J.P. \& Horst R.L. 2011. Prevalence of subclinical hypocalcemia in dairy herds. Vet. J.188(1):122-124. http:// dx.doi.org/10.1016/j.tvjl.2010.03.025. PMid:20434377.

Rodrigues F.A. 2009. Tratamento adicional da acidose láctica ruminal aguda em bovinos por meio de infusão de solução salina hipertônica (7,2\%). Dissertação de Mestrado, Faculdade de Medicina Veterinária e Zootecnia, Universidade de São Paulo, São Paulo. 118p. http://dx.doi. org/10.11606/D.10.2009.tde-08122009-114630.

Russell K.E. \& Roussel A.J. 2007. Evaluation of the ruminant serum chemistry profile. Vet. Clin. N. Am., Food Anim. Pract. 23(3):403-426, v. http://dx.doi. org/10.1016/j.cvfa.2007.07.003. PMid:17920455.

Sousa J.C., Conrad J.H., Mott G.O., McDowell L.R., Ammerman C.B. \& Blue W.G. 1982. Inter-relações entre minerais no solo, plantas forrageiras e tecido animal no norte do Mato Grosso. 4. Zinco, magnésio, sódio e potássio. Pesqui. Pesq. Agropec. Bras. 17:11-20.

Tajik J. \& Nazifi S. 2011. Diagnosis of subacute ruminal acidosis: a review. Asian J. Anim. Sci. 5(2):80-90. http://dx.doi.org/10.3923/ajas.2011.80.90.

Tedesco D., Tava A., Galletti S., Tameni M., Varisco G., Costa A. \& Steidler S. 2004. Effects of silymarin, a natural hepatoprotetor, in periparturient dairy cows. J. Dairy Sci. 87(7):2239-2247. http://dx.doi.org/10.3168/ jds.S0022-0302(04)70044-2. PMid:15328238.

Tokarnia C.H., Dobereiner J. \& Peixoto P.V. 2000. Deficiências minerais em animais de fazenda, principalmente bovinos em regime de campo. Pesq. Vet. Bras. 20(3):127-138. http://dx.doi.org/10.1590/S0100-736X2000000300007.

Wittwer F. 2000. Diagnóstico dos desequilíbrios metabólicos de energia em rebanhos bovinos, p.9-22. In: González F.H.D., Barcellos J.O., Ospina H. \& Ribeiro L.A. (Eds), Perfil Metabólico em Ruminantes: seu uso em nutrição e doenças nutricionais. Universidade Federal do Rio Grande do Sul, Porto Alegre. 